\title{
Please add some clarity to transfusion thresholds-It makes my head spin!
}

\author{
Victor A. Ferraris, MD, PhD
}

\author{
From the Department of Surgery, University of Kentucky, Lexington, Ky. \\ Disclosures: Author has nothing to disclose with regard to commercial support. \\ Received for publication Nov 12, 2018; revisions received Nov 20, 2018; accepted for publication Nov 21, 2018; \\ available ahead of print Dec 28, 2018. \\ Address for reprints: Victor A. Ferraris, MD, PhD, University of Kentucky, A301 Kentucky Clinic, 740 S Lime- \\ stone, Lexington, KY (E-mail: ferraris@uky.edu) \\ J Thorac Cardiovasc Surg 2019;157:1043-4 \\ $0022-5223 / \$ 36.00$ \\ Copyright (C) 2018 by The American Association for Thoracic Surgery \\ https://doi.org/10.1016/j.jtcvs.2018.11.070
}

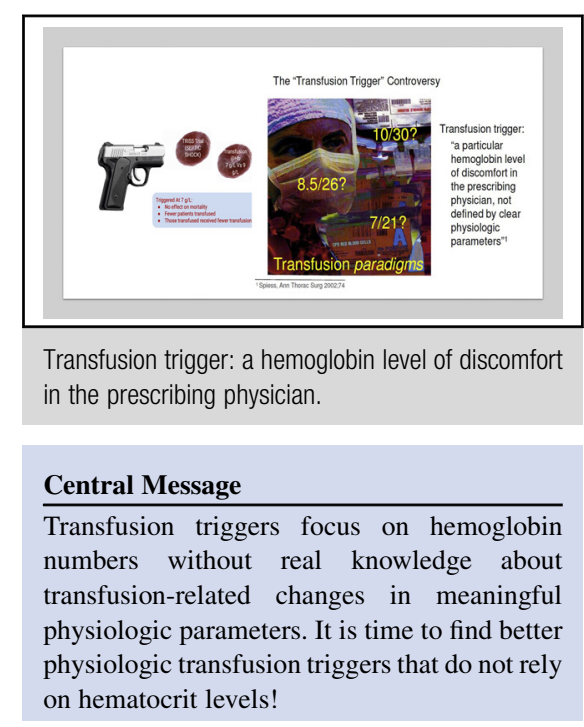

See Article page 1038.
It is rare that an issue requires as much evidence to formulate a clear recommendation as does the question of blood transfusion thresholds during cardiac operations. By my somewhat hasty count of MEDLINE articles that deal with this topic, there are at least 150 articles during the last 20 years that address the issue of a restrictive versus liberal transfusion threshold applied to surgical patients. Reading the literature makes your head spin, because there are so many articles that say very similar things. The overwhelming majority of these articles suggest that a restrictive threshold is as safe and effective as a more liberal transfusion threshold. Usually, a safe restrictive threshold is defined as a blood hemoglobin level of 7.0 to $7.5 \mathrm{~g} / \mathrm{dL}$, and a liberal threshold as somewhere between 8.5 and $10.0 \mathrm{~g} / \mathrm{dL}$. The commentary by Levy and Steiner ${ }^{1}$ in this issue of the Journal says that enough is enough. We do not need another study that proves that a restrictive threshold is safe and effective-more head spinning.

Levy and Steiner ${ }^{1}$ correctly focus on tissue oxygen delivery as a key indicator for decisions about transfusion, especially in children., 2,3 Their article summarizes some of the latest trial results that address the issue of liberal versus restrictive transfusion thresholds in cardiac surgical patients. A couple of sentences sum up their message ${ }^{1}$ : [W] therefore treat numerical values of hemoglobin rather than define an appropriate physiologic threshold for each particular patient. Again, we, unfortunately, do not have the ability to readily measure specific oxygen delivery or oxygen debt, and as a result treat specific hemoglobin thresholds instead."

Clinical trials that focus on RBC transfusion thresholds may miss the main point. Transfusions increase hemoglobin levels, but oxygen delivery to tissues may not be increased due to multiple factors, and augmenting oxygen delivery and utilization is much more important than treatment to a hemoglobin target. ${ }^{3}$ 
less immediately recognizable. Complications from application of a liberal transfusion threshold are much more subtle, and they often are not recognized by cardiac surgeons. It is not surprising that many cardiac surgeons resist strict adoption of a restrictive transfusion threshold. As Levy and Steiner ${ }^{1}$ suggest, there is even more uncertainty about platelet transfusions when they refer to the scant evidence base to guide platelet transfusions in bleeding cardiac surgical patients.

So, where do we go from here? Well, the obvious answer is that we need more evidence. Red blood cell transfusions do more than increase hemoglobin levels. They almost always improve oxygen carrying capacity, but to a highly variable extent that depends on many known and unknown factors. The key target for red blood cell transfusion is tissue oxygen content improvement. There are multiple factors that affect tissue oxygenation that include red blood cell quality (mainly related to age of transfused red blood cells), ${ }^{4}$ ability to deliver oxygen to tissues in need (possibly reliant on transport or flow properties), and ability to release oxygen from red cells across the interstitial space and ultimately to cross cell membranes into the cellular cytoplasm and mitochondria of cells in need. This multistep process involves oxygen delivery, oxygen transport, and adequate intracellular mechanisms to use delivered oxygen. There is no single test that measures this multistep process-no wonder we focus on hemoglobin levels! Some intriguing possibilities are lurking in the research halls, including using maximal oxygen uptake to indicate red blood cell function, ${ }^{5}$ noninvasive measurement of muscle oxygen, ${ }^{6}$ or even use of some point-of-care tests that identify oxygen debt. ${ }^{7,8}$ An essential first step in embracing new technology to assess anemia-related tissue hypoxia, however, is realizing that our current assessment tools are imprecise. The article by Levy and Steiner ${ }^{1}$ hints at these research needs, and it is to be hoped that their editorial will stimulate activity toward development of a better physiologic trigger that indicates a need for transfusion, and that serves as an indicator of adequacy of red blood cell-related tissue oxygenation. It is entirely possible that cardiothoracic surgeons would accept a need for transfusion that is based on improving physiologic measurements, rather than one based on a hemoglobin number.

\section{References}

1. Levy JH, Steiner ME. How to interpret recent restrictive transfusion trials in cardiac surgery: more new data or new more data? J Thorac Cardiovasc Surg. 2019; 157:1038-40.

2. Doctor A, Cholette JM, Remy KE, Argent A, Carson JL, Valentine SL, et al; Pediatric Critical Care Transfusion and Anemia Expertise Initiative (TAXI); Pediatric Critical Care Blood Research Network (BloodNet), and the Pediatric Acute Lung Injury and Sepsis Investigators (PALISI) Network. Recommendations on RBC transfusion in general critically ill children based on hemoglobin and/or physiologic thresholds from the Pediatric Critical Care Transfusion and Anemia Expertise Initiative. Pediatr Crit Care Med. 2018;19(9S Suppl 1): S98-113.

3. Spitalnik SL, Triulzi D, Devine DV, Dzik WH, Eder AF, Gernsheimer T, et al; State of the Science in Transfusion Medicine Working Groups. 2015 proceedings of the National Heart, Lung, and Blood Institute's State of the Science in Transfusion Medicine symposium. Transfusion. 2015;55:2282-90.

4. Stowell CP, Whitman G, Granger S, Gomez H, Assmann SF, Massey MJ, et al. The impact of red blood cell storage duration on tissue oxygenation in cardiac surgery. J Thorac Cardiovasc Surg. 2017;153:610-9.e612.

5. Bennett-Guerrero E, Lockhart EL, Bandarenko N, Campbell ML, Natoli MJ, Jamnik VK, et al. A randomized controlled pilot study of VO2 max testing: a potential model for measuring relative in vivo efficacy of different red blood cell products. Transfusion. 2017;57:630-6.

6. Schenkman KA, Hawkins DS, Ciesielski WA, Delaney M, Arakaki LS. Non-invasive assessment of muscle oxygenation may aid in optimising transfusion threshold decisions in ambulatory paediatric patients. Transfus Med. 2017;27: 25-9.

7. Bjerkvig CK, Strandenes G, Eliassen HS, Spinella PC, Fosse TK, Cap AP, et al. "Blood failure" time to view blood as an organ: how oxygen debt contributes to blood failure and its implications for remote damage control resuscitation. Transfusion. 2016;56(Suppl 2):S182-9.

8. Weinberg JA, Patel RP. Red blood cell transfusion and its effect on microvascular dysfunction in shock states. Best Pract Res Clin Anaesthesiol. 2016;30: 491-8. 